\title{
The anti-inflammatory and potential anti-atherogenic effect of insulin: a new paradigm
}

\author{
P. Dandona, A. Aljada, P. Mohanty \\ Division of Endocrinology, Diabetes and Metabolism, State University of New York at Buffalo, and Kaleida Health, Buffalo, \\ New York, USA
}

Hyperinsulinaemia has been known to be associated with an increase in coronary heart disease and atherosclerosis for sometime [1-4]. However, this association has not been shown in all studies nor has it been shown to occur in women. In a large study involving elderly patients, this association was absent [5]. In the absence of an obvious explanation for the increased occurrence of heart attacks and strokes in hyperinsulinaemic patients, it was proposed that insulin was an atherogenic hormone. Data based on in vitro experiments was proposed as the mechanism underlying this putative effect of insulin. For example, MAP kinase-dependent mechanisms, which are stimulated by high insulin concentrations and trigger mitosis and increased expression of plasminogen activator inhibitor-1 (PAI-1) in vascular smooth muscle cells, were suggested as the mechanisms underlying hyperinsulinaemia-associated atherogenicity [6,7].

Received: 28 August 2001 and in revised form: 20 November 2001

Corresponding author: P.Dandona, Diabetes-Endocrinology Center of Western New York, Professor of Medicine, State University of New York at Buffalo, 3 Gates Circle, Buffalo, NY 14209, USA, e-mail: pdandona@kaleidahealth.org

Abbreviations: MAPK, Mitogen-activated protein kinase; PAI-I, plasminogen activator inhibitor-1; VSMC, vascular smooth muscle cells; PDGF, platelet-derived growth factor; $\mathrm{HGH}$, human growth hormone; CRP, c-reactive protein; IL-6, interleukin-6; LPS, lipopolysaccharide; IКB, inhibitor $\kappa \mathrm{B}$; $N F-\kappa \mathrm{B}$, nuclear factor; $I L-1 \beta$, interleukin- $1 \beta$; ICAM-1, intercellular adhesion molecule-1; sICAM-1, soluble ICAM-1; VCAM-1, vascular cell adhesion molecule-1; MCP-1, monocyte chemoattractant protein-1; MNC, mononuclear cells; HAEC, human aortic endothelial cells; NOS, nitric oxide synthase; L-NNA, N(G)-nitro-L-arginine; AP-1, activator protein1; MMPs, matric metalloproteinases; Egr-1, early growth response gene-1; TF, tissue factor; IKK $\alpha$, IкB Kinase $\alpha$; $I K K \beta$, IкB Kinase $\beta$; ROS, reactive oxygen species; HMG-CoA, 3-hydroxy-3-methylglutaryl CoA
Since atherosclerosis involves mitosis and an increase in the cellularity of the arterial wall, the effect of insulin on p21 Ras signalling was investigated. p21 Ras signalling is considered important for the cellular effects of growth factors and their synergism with insulin. Insulin at pharmacological concentrations increases farnesyltransferase activity and thus the farnesylation of p21 Ras in the cytosol in VSMC. Moreover, farnesylated p21 Ras translocates to the membrane and is ready for activation by other growth factors like PDGF [8]. p21 Ras activation is also promoted by GTP-loading and inhibited by hyperphosphorylation, processes which are appropriately modulated by insulin [9]. p21 Ras activation in turn stimulates MAP kinase and the mitogenic stimulation dependent on this pathway in 3T3-L1 fibroblasts. It was suggested that insulin could exert a pro-atherogenic effect through these growth promoting actions. These effects were observed in vitro at concentrations of 10 to $100 \mathrm{nmol} / \mathrm{l}$ of insulin $(=1400-14000 \mu \mathrm{U} / \mathrm{ml})$ [10-12]. Such concentrations of insulin have not been observed in vivo, even in patients with obesity and insulin resistance and have been rarely observed in patients with extreme insulin resistance and severe acanthosis nigricans [13]. Furthermore, chronic hyperinsulinaemia associated with insulinoma is not associated with atherosclerosis [14]. The state of human growth hormone $(\mathrm{HGH})$ deficiency is associated with low insulin concentrations and an increased risk of atherosclerosis [15-17]. Though this increased risk is considered an effect of HGH deficiency, it is possible that low insulin concentrations contribute to it. Of interest, the increased concentrations of inflammatory mediators, c-reactive protein (CRP) and interleukin6 (IL-6) decrease with HGH therapy while insulin concentration increases [18].

According to the evolving concept of inflammation at the cellular and molecular levels we now know that proinflammatory stimuli like lipopolysac- 
charide (LPS) and pro-inflammatory cytokines, like tumour necrosis factor- $\alpha(\mathrm{TNF} \alpha)$ and IL- 6 , cause phosphorylation of inhibitor $\kappa \mathrm{B}$ (I $\mathrm{KB})$ and subsequent translocation of nuclear factor $\kappa \mathrm{B}(\mathrm{NF}-\kappa \mathrm{B})$ to the nucleus. Intranuclear $\mathrm{NF}-\kappa \mathrm{B}$ induces the transcription of proinflammatory genes like $\mathrm{TNF} \alpha$, IL-6, interleukin-1 $\beta$ (IL-1 $\beta$ ), adhesion molecules like intercellular adhesion molecule-1 (ICAM-1) and vascular cell adhesion molecule-1 (VCAM-1), chemokines like monocyte chemoattractant protein-1 (MCP-1) and CRP [19-23]. Using these principles we recently showed that hydrocortisone, a glucocorticoid, induces I $\kappa \mathrm{B}$ and suppresses intranuclear NF- $\kappa \mathrm{B}$ in mononuclear cells (MNC), in vivo [24]. The use of the circulating MNC allowed us to investigate pro-inflammatory and anti-inflammatory actions of several drugs and/or agents in vivo [24-27].

We have also shown that insulin has a potent antiinflammatory effect. This effect was observed in human aortic endothelial cells (HAEC) in vitro [28, 29], and in MNC, in vivo [30]. Thus, insulin at physiologically relevant concentrations causes a suppression of intranuclear NF- $\mathrm{KB}$, ICAM-1 and MCP-1 in HAEC in vitro [28, 29]. These effects could be related to the ability of insulin to induce the release of nitric oxide [31] and to enhance the expression of constitutive nitric oxide synthase (NOS) [32] because the ICAM-1 suppressive effect of insulin can be prevented by inhibiting NOS by N(G)-nitro-L-arginine (LNNA) [29]. There is considerable evidence that nitric oxide has an anti-atherosclerotic effect and that its inhibition is pro-atherogenic $[33,34]$. The infusion of a low dose of insulin to achieve concentrations of 24-30 $\mu \mathrm{U} / \mathrm{ml}$ into obese subjects, led to the suppression of intranuclear NF- $\kappa \mathrm{B}$, a decrease in the $\mathrm{p} 47^{\text {phox }}$ subunit of NADPH oxidase (the enzyme which converts molecular $\mathrm{O}_{2}$ to superoxide, $\mathrm{O}_{2}^{--}$), radical and a decrease in CRP, sICAM-1 and MCP-1. There was also an increase in cellular I $\mathrm{B}$, which binds NF- $\mathrm{NB}$ and prevents its translocation into the nucleus, thus inhibiting the transcriptional action of NF- $\mathrm{kB}$ [21]. These effects of insulin are rapid, profoundly anti-inflammatory and probably anti-atherogenic in the long-term. Atherosclerosis is now recognised as an inflammation of the arterial wall and thus the action of NF- $\kappa \mathrm{B}$ is considered central to atherosclerosis because it induces the transcription of pro-inflammatory molecules. NF- $\kappa \mathrm{B}$ expression in atherosclerotic plaques is known to be consistent [35].

Thus insulin has a suppressive effect on NF- $\kappa \mathrm{B}$ with a corresponding reduction in the expression of pro-inflammatory genes. It also suppresses activator protein-1 (AP-1) [36], the transcription factor which modulates matrix metalloproteinases (MMPs), expressed in the atherosclerotic plaque and could be responsible for plaque rupture [37, 38]. In addition, it suppresses early growth response gene-1 (Egr-1) [39], the transcription factor which modulates tissue factor (TF) which, in turn activates thrombin generation. These effects indicate that insulin could have a key inhibitory role in the regulation of factors which are central to atherogenesis, plaque rupture and thrombosis, the final events which precipitate acute myocardial or cerebral ischemia and infarction. The successful use of insulin in acute myocardial infarction, with and without the use of thrombolytics in diabetic patients and non-diabetic subjects in improving clinical outcomes [40], might reflect the profound anti-inflammatory and potential anti-thrombotic properties of insulin.

Potentiation by pre-incubation with insulin on angiotensin II, AGE and glucose induced increases in $\mathrm{NF}-\kappa \mathrm{B}$ expression in VSMC was reported, but no data have been provided [41] on the direct effect of insulin on $\mathrm{NF}-\kappa \mathrm{B}$. It is possible that pre-incubation with insulin reduced the NF- $\kappa \mathrm{B}$ in these cells and thus the NF- $\kappa \mathrm{B}$ stimulatory effect of the pro-inflammatory agents was amplified because the results were expressed as percentage increase. The direct action of insulin on NF- $\mathrm{KB}$ in VSMC requires careful reassessment. Furthermore, insulin has an inhibitory effect (NF- $\mathrm{KB}$ suppression) on the two cells which initiate atherosclerotic inflammation, endothelial cells [28] and the MNC [30]. Furthermore, the NF- $\kappa B$ suppressive effect of insulin has been shown in humans in vivo, at physiologically relevant concentrations. Recent work has also shown that insulin reduces the adhesion of inflammatory cells to the endothelium in vivo in experimental animals [42].

Our series of observations on insulin sensitizers of the thiazolidinedione class are consistent with our observation on the anti-inflammatory effects of insulin: both troglitazone and rosiglitazone are profoundly anti-inflammatory with inhibitory effects on the transcription factor NF- $\kappa$ B. Troglitazone has also been shown to inhibit AP-1 and Egr-1 and the respective pro-inflammatory matrix dissolving (MMPs) and pro-thrombotic (TF) genes which they modulate [25, 27, 43, 44]. Thus, thiazolidinediones suppress the plasma concentrations of TNF $\alpha$, sICAM-1, MCP-1, CRP, MMP-2, MMP-9 and TF. Troglitazone also caused a small but significant increase in plasma interleukin-10 (IL-10) [25], an anti-inflammatory cytokine secreted by $\mathrm{Th}_{2}$ cells $[45,46]$. This enhancing effect by IL-10 is also observed with glucocorticoids. It is intriguing that the decrease in plasma insulin concentrations following troglitazone in the obese is rapid and it parallels the impressive decrease in intranuclear NF- $\kappa \mathrm{B}$ concentration and reactive oxygen species (ROS) generation by MNC. It is possible that insulin resistance and inflammation are closely and possibly causally related. The rapid, profound and consistent ROS suppressive anti-inflammatory effects of troglitazone [25, 43, 47] and rosiglitazone [27] allow us to anticipate also their anti-atherogenic action in the long-term. Indeed, short-term treatment 
(3 to 6 months) with troglitazone and pioglitazone have been shown to reduce the intimal medial thickness of the internal carotid artery [48], [49]. Troglitazone and rosiglitazone have also been shown to improve post-ischemic endothelium mediated vasodilatation [27, 47] and to improve vasospastic angina [50]. The ability of insulin to induce an acute release of nitric oxide [31] from endothelial cells and to increase the expression of eNOS [32] in these cells is associated with an acute vasodilatory effect. This effect has been observed as an increase in the blood flow of lower [51] and upper limbs [52] and the dilation of the internal carotid artery after systemic insulin infusion [53]. It has also been shown in the veins of the hand and the wrist where the vasodilatory response occurs within 3 to $5 \mathrm{~min}$ at the site of infusion, indicating that insulin has a direct action on the vessel walls in vivo $[54,55]$. It is, therefore, not surprising that insulin resistant states of obesity and Type II (non-insulin-dependent) diabetes mellitus are associated with impaired vasodilatory responses [56-59]. Consistent with this concept, insulin sensitizers like troglitazone and rosiglitazone, have profound beneficial effects on vascular reactivity while they reverse insulin resistance and actually lower plasma insulin concentrations $[27,47,50]$. Whether TZDs increase insulin-induced nitric oxide release or have a direct action on nitric oxide release from endothelial cells has yet to be shown. It is also of interest that pro-inflammatory cytokines like $\mathrm{TNF} \alpha$, increased in the obese, might not only promote inflammation and atherogenesis but could reduce the vasodilatory effect of insulin through the inhibition of insulin induced eNOS expression, insulin receptor tyrosine phosphorylation and actual reduction in insulin content [60]. Of note, troglitazone and rosiglitazone treatments reduce plasma TNF $\alpha$ concentrations.

In contrast to these actions of insulin and insulin sensitizers, we now know that macronutrient intake in the pure form as carbohydrates, fats, proteins, and mixed meals cause oxidative stress and lead to $\mathrm{NF}-\mathrm{\kappa B}$ increase in the nucleus and in a pro-inflammatory state [61-63]. Glucose intake (75 g) and a mixed meal intake, result in an increase in the expression of I $\kappa$ B kinase- $\alpha$ (IKK $\alpha$ ), which phosphorylates $\mathrm{I} \kappa \mathrm{B}$, results in its ubiquitination and causes its content to decrease. Indeed, the ratio of phosphorylated to non-phosphorylated IкB increases after glucose challenge. This allows NF- $\kappa \mathrm{B}$ to translocate into the nucleus to induce the transcription of proinflammatory cytokines, adhesion molecules, chemokines and enzymes generating ROS. Evidence of an increase in lipid peroxidation after glucose or mixed meal intake has been shown [64]. We have also shown that obesity is associated with a marked increase in oxidative stress and an increase in inflammatory mechanisms (increased plasma $\mathrm{TNF} \alpha$ ) [65]. CRP has also been shown to be increased [66].
An assessment of the NF- $\kappa \mathrm{B} / \mathrm{I} \kappa \mathrm{B}$ status in the obese has yet to be done.

Since insulin is secreted in response to macronutrient intake, the subsequent action of insulin should be looked at not merely in terms of its ability to normalize glucose, lipid, and amino acid concentrations (the classic paradigm); therefore we have conceptualised a new paradigm in which macronutrients and food are potentially pro-inflammatory and whereby insulin is anti-inflammatory and is secreted in response to these agents. The epitome of excessive food intake, the state of obesity, is characterized by pro-oxidant stress and inflammation which cannot be controlled by insulin in spite of marked increases in its plasma concentrations both in the fasting and the post-prandial state. This is the state of insulin resistance in terms of metabolism and inflammation. It is remarkable that 4 weeks of dietary restriction in the obese results in a marked reduction in oxidative stress, including ROS generation by leucocytes, lipid peroxidation and protein carbonylation without the use of antioxidants [65]. Plasma TNF $\alpha$ concentrations are also increased in the obese and tend to decrease with long-term weight loss [67]. Whether there is a single metabolic step at which the nutrition-induced pro-inflammatory state converges with that of metabolic insulin resistance is not known. Current studies have focused on IKK $\beta$, the enzyme that phosphorylates IкB as a possible site where the pro-inflammatory and metabolic cascades could converge; this hypothesis is supported by the fact that aspirin inhibits this enzyme and also causes a reduction in plasma glucose concentrations in the rat models of obesity and diabetes. Furthermore, targeted disruption of IKK $\beta$ protects animals from insulin resistance [68]. In addition, salicylates protect animals from fat-induced insulin resistance [69]. It has been suggested that Type II diabetes itself could be a proinflammatory state [70].

Thus, insulin is an anti-inflammatory hormone and insulin resistant states, including obesity and polycystic ovary syndrome (plasma TNF $\alpha$ concentrations are increased), are pro-inflammatory. While these states are pro-atherogenic, insulin is anti-inflammatory and probably anti-atherogenic in the long-term. The novel ROS suppressive and anti-inflammatory effect of insulin should be compared with that of glucocorticoids, the classic anti-inflammatory drugs or hormones. Our observations suggest that $100 \mathrm{mg}$ of hydrocortisone has a ROS suppressive and NF- $\kappa \mathrm{B}$ suppressive effect, comparable to that of $2 \mathrm{IU} / \mathrm{h}$ of insulin $(25-30 \mu \mathrm{U} / \mathrm{ml})$ and similar to that of $4 \mathrm{mg}$ of dexamethasone [24, 71, 72]. Hydrocortisone also suppresses AP-1 [73], another pro-inflammatory transcription factor, as well as suppressing plasma MMP-2 concentration. AP-1 induces an increase in the expression of MMP-9 and MMP-2 genes. Insulin inhibits AP-1, MMP-2 and MMP-9 in a similar way to hydrocortisone [36]. Thus, insulin is anti-inflammatory 

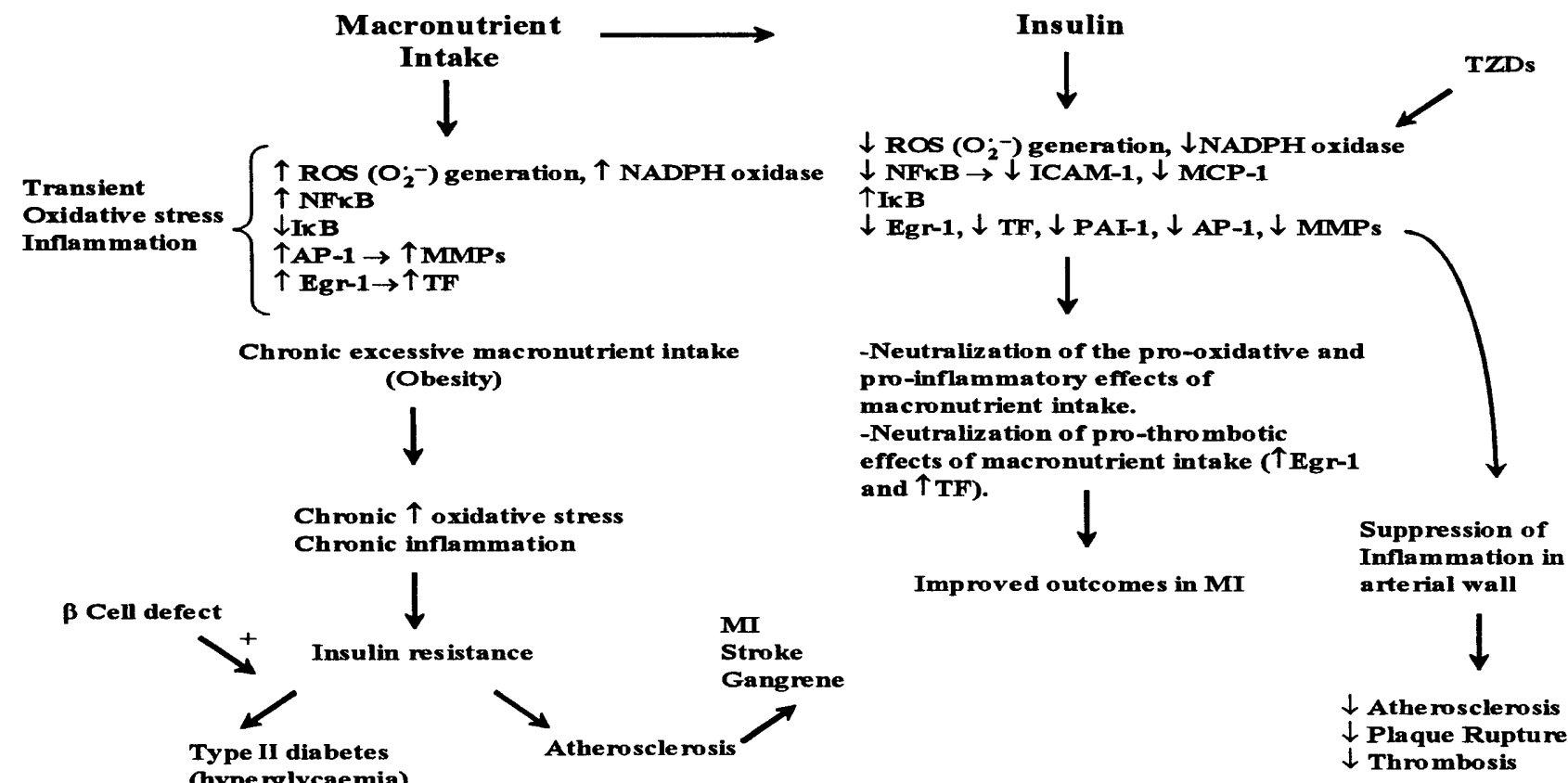

Fig. 1. The pro-oxidant and the pro-inflammatory effects of macronutrient intake, the relation to chronic overnutrition (obesity) and insulin resistance; the anti-inflammatory effects of insulin and TZDs. In addition to NF- $\kappa \mathrm{B}$ regulated pro-inflammatory genes, glucose stimulates and insulin and TZDs inhibit AP-1, MMPs, and Egr-1 and TF, the major regulators of atherosclerotic plaque rupture and thrombosis

at physiological concentrations and could exert an anti-inflammatory effect, especially in the post-prandial period as a physiological function. The basic difference in the action of insulin when compared with that of glucocorticoids probably lies in the anabolic effect of insulin: increasing glycogen, protein and lipid synthesis and storage, while decreasing hepatic glucose production through the inhibition of gluconeogenesis and glycogenolysis. In contrast, glucocorticoids are catabolic: they increase gluconeogenesis, causing protein breakdown and lipolysis.

The chronic caloric overload in obesity thus results in a state of chronic oxidative stress and pro-inflammatory changes. These changes contribute to or directly cause insulin resistance which then leads to atherosclerosis and Type II diabetes particularly if there is a concomitant defect in beta-cell function (Fig. 1).

In the Women's Health study, the increase of plasma IL-6 and/or CRP concentrations was associated with the future occurrence of Type II diabetes in obese women over a 4-year follow-up. The multivariate analysis confirmed that the association between increased CRP and IL-6 was independent of obesity, hypertension, hyperlipidaemia, smoking and a family history of diabetes mellitus [74]. This would be consistent with the pre-diabetic insulin resistant state being proinflammatory. Similarly, a reduction in the incidence of Type II diabetes in patients treated with ramipril [75, 76], an ACE-inhibitor, and pravastatin [77], a 3-hydroxy-3-methylglutaryl CoA (HMGCoA) reductase inhibitor, are consistent with Type II diabetes being an inflammatory state since ACE inhibitors and HMG-CoA reductase inhibitors could have anti-inflammatory effects.

This novel action of insulin has found clinical application in the DIGAMI [78] and ECLA [79] studies, which have shown that low dose insulin infusions benefit the clinical outcomes of both diabetic and non-diabetic patients with acute myocardial infarction. A recent study in ventilated patients in a surgical intensive care unit showed remarkable improvements in the mortality and morbidity after low dose infusions of insulin [80].

In conclusion, insulin is not just an anabolic hormone which lowers blood glucose concentrations, it exerts a potent anti-inflammatory effect which could contribute to an anti-atherogenic effect in the longterm. Similarly, macronutrients induce oxidative stress and are potentially pro-inflammatory. It is thus, rational to assert that insulin, a hormone secreted in response to nutritional intake, is anti-inflammatory.

Acknowledgements. The authors acknowledge the valuable critical comments and help from H. Ghanim, D. Tripathy, A. Chaudhuri and A. Bandyopadhyay. This work was supported by the William G. McGowan Charitable Fund. 


\section{References}

1. Festa A, D’Agostino R Jr, Mykkanen L et al. (1999) Relative contribution of insulin and its precursors to fibrinogen and PAI-1 in a large population with different states of glucose tolerance. The Insulin Resistance Atherosclerosis Study (IRAS). Arterioscler Thromb Vasc Biol 19: 562-568

2. Kekalainen P, Sarlund H, Farin P, Kaukanen E, Yang X, Laakso M (1996) Femoral atherosclerosis in middle-aged subjects: association with cardiovascular risk factors and insulin resistance. Am J Epidemiol 144: 742-748

3. Stout RW (1991) Insulin as a mitogenic factor: role in the pathogenesis of cardiovascular disease. Am J Med 90: 62S$65 \mathrm{~S}$.

4. Stout RW (1992) Insulin and atherogenesis. Eur J Epidemiol 8 [Suppl 1]: 134-135

5. Wingard DL, Barrett-Connor EL, Ferrara A (1995) Is insulin really a heart disease risk factor. Diabetes Care 18: 1299-1304

6. Pandolfi A, Iacoviello L, Capani F, Vitacolonna E, Donati MB, Consoli A (1996) Glucose and insulin independently reduce the fibrinolytic potential of human vascular smooth muscle cells in culture. Diabetologia 39: 1425-1431

7. Begum N, Song Y, Rienzie J, Ragolia L (1998) Vascular smooth muscle cell growth and insulin regulation of mitogen- activated protein kinase in hypertension. Am J Physiol 275: C42-C49

8. Goalstone ML, Natarajan R, Standley PR et al (1998) Insulin potentiates platelet-derived growth factor action in vascular smooth muscle cells. Endocrinology 139: 4067-4072

9. Goalstone ML, Draznin B (1998) What does insulin do to Ras? Cell Signal 10: 297-301

10. Alessi MC, Juhan-Vague I, Kooistra T, Declerck PJ, Collen D (1988) Insulin stimulates the synthesis of plasminogen activator inhibitor 1 by the human hepatocellular cell line Hep G2. Thromb Haemost 60: 491-494

11. Schneider DJ, Sobel BE (1991) Augmentation of synthesis of plasminogen activator inhibitor type 1 by insulin and insulin-like growth factor type I: implications for vascular disease in hyperinsulinemic states. Proc Natl Acad Sci USA 88: 9959-9963

12. Banfi C, Eriksson P, Giandomenico G et al. (2001) Transcriptional regulation of plasminogen activator inhibitor type 1 gene by insulin: insights into the signaling pathway. Diabetes 50: 1522-1530

13. Kahn CR, Flier JS, Bar RS, Archer JA, Gorden P, Martin MM, Roth J (1976) The syndromes of insulin resistance and acanthosis nigricans. Insulin- receptor disorders in man. N Engl J Med 294: 739-745

14. Leonetti F, Iozzo P, Giaccari A et al. (1993) Absence of clinically overt atherosclerotic vascular disease and adverse changes in cardiovascular risk factors in 70 patients with insulinoma. J Endocrinol Invest 16: 875-880

15. Markussis V, Beshyah SA, Fisher C, Sharp P, Nicolaides AN, Johnston DG (1992) Detection of premature atherosclerosis by high-resolution ultrasonography in symptomfree hypopituitary adults. Lancet 340: 1188-1192

16. Capaldo B, Patti L, Oliviero U et al. (1997) Increased arterial intima-media thickness in childhood-onset growth hormone deficiency. J Clin Endocrinol Metab 82: 1378-1381

17. Pfeifer M, Verhovec R, Zizek B, Prezelj J, Poredos P, Clayton RN (1999) Growth hormone $(\mathrm{GH})$ treatment reverses early atherosclerotic changes in GH-deficient adults. J Clin Endocrinol Metab 84: 453-457

18. Sesmilo G, Biller BM, Llevadot J et al. (2000) Effects of growth hormone administration on inflammatory and other cardiovascular risk markers in men with growth hor- mone deficiency. A randomized, controlled clinical trial. Ann Intern Med 133: 111-122

19. Baeuerle PA, Henkel T (1994) Function and activation of NF-kappa B in the immune system. Annu Rev Immunol 12: $141-179$

20. Baeuerle PA, Baltimore D (1996) NF-kappa B: ten years after. Cell 87: 13-20

21. Baldwin AS Jr (1996) The NF-kappa B and I kappa B proteins: new discoveries and insights. Annu Rev Immunol 14: 649-683

22. Barnes PJ, Karin M (1997) Nuclear factor-kappaB: a pivotal transcription factor in chronic inflammatory diseases. N Engl J Med 336: 1066-1071

23. Liou HC, Baltimore D (1993) Regulation of the NF-kappa $\mathrm{B} /$ rel transcription factor and I kappa B inhibitor system. Curr Opin Cell Biol 5: 477-487

24. Aljada A, Ghanim H, Assian E et al. (1999) Increased IkappaB expression and diminished nuclear NF-kappaB in human mononuclear cells following hydrocortisone injection. J Clin Endocrinol Metab 84: 3386-3389

25. Ghanim H, Garg R, Aljada A et al. (2001) Suppression of nuclear factor-kappaB and stimulation of inhibitor kappaB by troglitazone: evidence for an anti-inflammatory effect and a potential antiatherosclerotic effect in the obese. J Clin Endocrinol Metab 86: 1306-1312

26. Dandona P, Karne R, Ghanim H et al. (2000) Carvedilol inhibits reactive oxygen species generation by leukocytes and oxidative damage to amino acids. Circulation 101: 122-124

27. Mohanty P, Aljada A, Ghanim H et al. (2001) Rosiglitazone improves vascular reactivity, inhibits reactive oxygen species (ROS) generation, reduces p47phox subunit expression in mononuclear cells (MNC) and reduces $\mathrm{C}$ reactive protein (CRP) and monocyte chemotactic protein-1 (MCP-1): evidence of a potent anti-inflammatory effect. Diabetes 50 [Suppl 2]: A68 (Abstract)

28. Aljada A, Ghanim H, Saadeh R, Dandona P (2001) Insulin inhibits NFkappaB and MCP-1 expression in human aortic endothelial cells. J Clin Endocrinol Metab 86: 450-453

29. Aljada A, Saadeh R, Assian E, Ghanim H, Dandona P (2000) Insulin inhibits the expression of intercellular adhesion molecule- 1 by human aortic endothelial cells through stimulation of nitric oxide. J Clin Endocrinol Metab 85: 2572-2575

30. Dandona P, Aljada A, Mohanty P (2001) Insulin inhibits intranuclear nuclear factor kappab and stimulates IkappaB in mononuclear cells in obese subjects: evidence for an anti- inflammatory effect? J Clin Endocrinol Metab 86: 3257-3265

31. Zeng G, Quon MJ (1996) Insulin-stimulated production of nitric oxide is inhibited by wortmannin. Direct measurement in vascular endothelial cells. J Clin Invest 98: 894-898

32. Aljada A, Dandona P (2000) Effect of insulin on human aortic endothelial nitric oxide synthase. Metabolism 49: 147-150

33. Cartwright JE, Whitley GS, Johnstone AP (1997) Endothelial cell adhesion molecule expression and lymphocyte adhesion to endothelial cells: effect of nitric oxide. Exp Cell Res 235: 431-434

34. Luvara G, Pueyo ME, Philippe M (1998) Chronic blockade of NO synthase activity induces a proinflammatory phenotype in the arterial wall: prevention by angiotensin II antagonism. Arterioscler Thromb Vasc Biol 18: 1408-1416

35. Brand K, Page S, Rogler G et al. (1996) Activated transcription factor nuclear factor-kappa $B$ is present in the atherosclerotic lesion. J Clin Invest 97: 1715-1722

36. Ghanim H, Mohanty P, Aljada A, Chowhan S, Tripathy D, Dandona P (2001) Insulin reduces the pro-inflammatory 
transcription factor, activation protein-1 (AP-1), in mononuclear cells (MNC) and plasma matrix metalloproteinase-9 (MMP-9) concentration. Diabetes 50 [Suppl 2]: A408 (Abstract)

37. Woessner JF Jr (1991) Matrix metalloproteinases and their inhibitors in connective tissue remodeling. FASEB J 5: 2145-2154

38. Galis ZS, Sukhova GK, Lark MW, Libby P (1994) Increased expression of matrix metalloproteinases and matrix degrading activity in vulnerable regions of human atherosclerotic plaques. J Clin Invest 94: 2493-2503

39. Aljada A, Ghanim H, Mohanty P, Kapur N, Dandona P (2002) Insulin Inhibits the Pro-Inflammatory Transcription Factor Early Growth Response Gene-1 (Egr)-1 Expression in Mononuclear Cells (MNC) and Reduces Plasma Tissue Factor (TF) and Plasminogen Activator Inhibitor-1 (PAI1) Concentrations. J Clin Endocrinol Metab 87: 1419-1422

40. Fath-Ordoubadi F, Beatt KJ (1997) Glucose-insulin-potassium therapy for treatment of acute myocardial infarction: an overview of randomized placebo-controlled trials. Circulation 96: 1152-1156

41. Golovchenko I, Goalstone ML, Watson P, Brownlee M, Draznin B (2000) Hyperinsulinemia enhances transcriptional activity of nuclear factor- kappaB induced by angiotensin II, hyperglycemia, and advanced glycosylation end products in vascular smooth muscle cells. Circ Res 87: 746-752

42. Booth G, Stalker TJ, Lefer AM, Scalia R (2001) Elevated ambient glucose induces acute inflammatory events in the microvasculature: effects of insulin. Am J Physiol Endocrinol Metab 280: E848-E856

43. Aljada A, Garg R, Ghanim H et al. (2001) Nuclear FactorkappaB Suppressive and Inhibitor-kappaB Stimulatory Effects of Troglitazone in Obese Patients with Type 2 Diabetes: Evidence of an Antiinflammatory Action? J Clin Endocrinol Metab 86: 3250-3256

44. Aljada A, Garg R, Ghanim H, Mohanty P, Dandona P (2001) Troglitazone reduces intranuclear activator protein (AP-1) in mononuclear cells (MNC) and plasma matrix metalloproteinase-9 (MMP-9) concentration. Diabetes 50 [Suppl 2]: A532 (Abstract)

45. Viola JP, Rao A (1999) Molecular regulation of cytokine gene expression during the immune response. J Clin Immunol 19: 98-108

46. Umetsu DT, DeKruyff RH (1997) Th1 and Th2 CD $4+$ cells in the pathogenesis of allergic diseases. Proc Soc Exp Biol Med 215: 11-20

47. Garg R., Kumbkarni Y, Aljada A et al. (2000) Troglitazone reduces reactive oxygen species generation by leukocytes and lipid peroxidation and improves flow-mediated vasodilatation in obese subjects. Hypertension 36: 430-435

48. Minamikawa J, Tanaka S, Yamauchi M, Inoue D, Koshiyama H (1998) Potent inhibitory effect of troglitazone on carotid arterial wall thickness in type 2 diabetes. J Clin Endocrinol Metab 83: 1818-1820

49. Koshiyama H, Shimono D, Kuwamura N, Minamikawa J, Nakamura Y (2001) Rapid communication: inhibitory effect of pioglitazone on carotid arterial wall thickness in type 2 diabetes. J Clin Endocrinol Metab 86: 3452-3456

50. Murakami T, Mizuno S, Ohsato K et al. (1999) Effects of troglitazone on frequency of coronary vasospastic-induced angina pectoris in patients with diabetes mellitus. Am J Cardiol 84: 92-94 A98 (Abstract)

51. Steinberg HO, Brechtel G, Johnson A, Fineberg N, Baron AD (1994) Insulin-mediated skeletal muscle vasodilation is nitric oxide dependent. A novel action of insulin to increase nitric oxide release. J Clin Invest 94: 1172-1179
52. Scherrer U, Randin D, Vollenweider P, Vollenweider L, Nicod P (1994) Nitric oxide release accounts for insulin's vascular effects in humans. J Clin Invest 94: 2511-2515

53. Chaudhuri A, Kanjwal Y, Mohanty P et al. (1999) Insulininduced vasodilatation of internal carotid artery. Metabolism 48: 1470-1473

54. Feldman RD, Bierbrier GS (1993) Insulin-mediated vasodilation: impairment with increased blood pressure and body mass. Lancet 342: 707-709

55. Grover A, Padginton C, Wilson MF, Sung BH, Izzo JL Jr, Dandona P (1995) Insulin attenuates norepinephrine-induced venoconstriction. An ultrasonographic study. Hypertension 25: 779-784

56. Dandona P, James IM, Newbury PA, Woollard ML, Beckett AG (1978) Cerebral blood flow in diabetes mellitus: evidence of abnormal cerebrovascular reactivity. BMJ 2: 325-326

57. Gaylarde, PM, Fonseca VA, Llewellyn G, Sarkany I, Thomas PK, Dandona P (1988) Transcutaneous oxygen tension in legs and feet of diabetic patients. Diabetes 37: 714-716

58. Laakso M, Edelman SV, Brechtel G, Baron AD (1992) Impaired insulin-mediated skeletal muscle blood flow in patients with NIDDM. Diabetes 41: 1076-1083

59. Menon RK, Grace AA, Burgoyne W, Fonseca VA, James IM, Dandona P (1992) Muscle blood flow in diabetes mellitus. Evidence of abnormality after exercise. Diabetes Care 15: 693-695

60. Aljada A, Ghanim H, Assian E, Dandona P (2002) Tumor necrosis factor-a inhibits insulin induced increase in endothelial nitric oxide synthase and reduces insulin receptor content and phosphorylation in human aortic endothelial cells. Metabolism 51: 487-491

61. Mohanty P, Hamouda W, Garg R, Aljada A, Ghanim H, Dandona P (2000) Glucose challenge stimulates reactive oxygen species (ROS) generation by leucocytes. J Clin Endocrinol Metab 85: 2970-2973

62. Mohanty P, Ghanim H, Hamouda W, Aljada A, Garg R, Dandona P (2002) Lipid or protein intake stimulates increased ROS generation by PMNL and MNC. Am J Clin Nutr 75: 767-772

63. Aljada A, Ghanim H, Mohanty P, Assian E, Dandona P (2000) Glucose intake stimulates intranuclear NFkB and p47phox in mononuclear cells. ENDO '2000, the 82nd Annual Meeting of the Endocrine Society, Toronto, Canada

64. Ceriello A, Bortolotti N, Motz E et al. (1999) Meal-induced oxidative stress and low-density lipoprotein oxidation in diabetes: the possible role of hyperglycemia. Metabolism 48: 1503-1508

65. Dandona P, Mohanty P, Ghanim H et al. (2001) The Suppressive Effect of Dietary Restriction and Weight Loss in the Obese on the Generation of Reactive Oxygen Species by Leukocytes, Lipid Peroxidation, and Protein Carbonylation. J Clin Endocrinol Metab 86: 355-362

66. Yudkin JS, Stehouwer CD, Emeis JJ, Coppack SW (1999) C-reactive protein in healthy subjects: associations with obesity, insulin resistance, and endothelial dysfunction: a potential role for cytokines originating from adipose tissue? Arterioscler Thromb Vasc Biol 19: 972-978

67. Dandona P, Weinstock R, Thusu K, Abdel-Rahman E, Aljada A, Wadden T (1998) Tumor necrosis factor-alpha in sera of obese patients: fall with weight loss. J Clin Endocrinol Metab 83: 2907-2910

68. Yuan M, Konstantopoulos N, Lee J et al. (2001) Reversal of obesity- and diet-induced insulin resistance with salicylates or targeted disruption of Ikkbeta. Science 293: 1673-1677 
69. Kim JK, Kim YJ, Fillmore JJ et al. (2001) Prevention of fat-induced insulin resistance by salicylate. J Clin Invest 108: 437-446

70. Pickup JC, Mattock MB, Chusney GD, Burt D et al. (1997) NIDDM as a disease of the innate immune system: association of acute- phase reactants and interleukin- 6 with metabolic syndrome X. Diabetologia 40: 1286-1292

71. Dandona P, Thusu K, Hafeez R, Abdel-Rahman E, Chaudhuri A (1998) Effect of hydrocortisone on oxygen free radical generation by mononuclear cells. Metabolism 47: 788-791

72. Dandona P, Mohanty P, Hamouda W, Aljada A, Kumbkarni Y, Garg R (1999) Effect of dexamethasone on reactive oxygen species generation by leukocytes and plasma interleukin-10 concentrations: a pharmacodynamic study. Clin Pharmacol Ther 66: 58-65

73. Aljada A, Ghanim H, Mohanty P, Hofmeyer D, Tripathy D, Dandona P (2001) Hydrocortisone Suppresses Intranuclear Activator-Protein-1 (AP-1) Binding Activity in Mononuclear Cells and Plasma Matrix Metalloproteinase 2 and 9 (MMP-2 and MMP-9). J Clin Endocrinol Metab 86: 59885991

74. Pradhan AD, Manson JE, Rifai N, Buring JE, Ridker PM (2001) C-reactive protein, interleukin 6, and risk of developing type 2 diabetes mellitus. JAMA 286: 327-334
75. Yusuf S, Sleight P, Pogue J, Bosch J, Davies R, Dagenais G (2000) Effects of an angiotensin-converting-enzyme inhibitor, ramipril, on cardiovascular events in high-risk patients. The Heart Outcomes Prevention Evaluation Study Investigators. N Engl J Med 342: 145-153

76. Hansson L, Lindholm LH, Niskanen L et al. (1999) Effect of angiotensin-converting-enzyme inhibition compared with conventional therapy on cardiovascular morbidity and mortality in hypertension: the Captopril Prevention Project (CAPPP) randomised trial. Lancet 353: 611-616

77. Freeman DJ, Norrie J, Sattar N et al. (2001) Pravastatin and the development of diabetes mellitus: evidence for a protective treatment effect in the West of Scotland Coronary Prevention Study. Circulation 103: 357-362

78. Malmberg K, Ryden, L, Efendic, S et al. (1995) Randomized trial of insulin-glucose infusion followed by subcutaneous insulin treatment in diabetic patients with acute myocardial infarction (DIGAMI study): effects on mortality at 1 year. J Am Coll Cardiol 26: 57-65

79. Diaz R, Paolasso EA, Piegas LS et al. (1998) Metabolic modulation of acute myocardial infarction. The ECLA (Estudios Cardiologicos Latinoamerica) Collaborative Group. Circulation 98: 2227-2234

80. Van den Berghe G, Wouters P, Weekers F et al. (2001) Intensive insulin therapy in critically ill patients. N Engl J Med 345: 1359-1367 